\title{
EFFECT OF PLANT DENSITY AND FERTILIZER LEVELS ON GROWTH PARAMETERS OF RICE VARIETIES UNDER LATE SOWN CONDITIONS
}

\author{
O. SAMPATH, A. SRINIVAS, K. AVIL KUMAR \& T. RAMPRAKASH \\ Department of Agronomy, College of Agriculture, Prof. Jayashankar Telangana State
}

Agricultural University, Rajendranagar, Hyderabad, India

\begin{abstract}
A field experiment was conducted on a sandy clay loam soil at college farm of Professor Jayashankar Telangana State Agricultural University, Rajendranagar, Hyderabad, Rajendranagar, Hyderabad, Telangana during the kharif seasons of 2014 and 2015 to study the growth parameters of rice varieties as influenced by combination of plant densities and fertilizers under late sown condition. Among the varieties, MTU 1010 performed superior to Pradyumna and Rajendra in terms of growth parameters.

KEYWORDS: FAOSTAT Database, Mohanty \& Oryza Sativa
\end{abstract}

Received: May 05, 2017; Accepted: May 25, 2017; Published: Jun 05, 2017; Paper Id.: IJASRJUN201748

\section{INTRODUCTION}

Rice (Oryza sativa (L.)) is one of the most important staple food crops in the world. However, more than 90 per cent of rice is consumed in Asia, where it is a staple food for a majority of the population, including the 560 million hungry people in the region (Mohanty, 2013). In Asia, more than two billion people are getting 60-70 per cent of their energy requirement from rice and its derived products. Among the rice growing countries, India has the largest area $(42.27 \mathrm{~m} \mathrm{ha})$ and it is the second largest producer $(105.24 \mathrm{~m} \mathrm{t})$ of rice next to China $(144 \mathrm{~m} \mathrm{t})$. With an average productivity of $2.49 \mathrm{t} \mathrm{ha}^{-1}$, though increasing marginally, but is still well below the world's average yield of $4.36 \mathrm{t} \mathrm{ha}^{-1}$ (FAOSTAT Database, 2014). At the current population growth rate $(1.5 \%)$, the rice requirement of India by 2025 would be around $125 \mathrm{~m} \mathrm{t}$ (Kumar et al., 2009). The importance of continuing to develop new rice varieties to guarantee India's food security and support the region's economic development needs no special emphasis. Varieties play a vital role in maximizing of yield by improving the input use efficiency. The adverse effect of late transplanting can also be minimized by selecting suitable cultivar as magnitude of yield reduction varies with the rice cultivars. Plant population exerts a strong influence on the rice growth and grain yield, because of its competitive effects, both on the vegetative and reproductive development. Optimum plant spacing ensures plants to grow properly both in their aerial and underground parts through utilization of solar radiation and nutrients, therefore proper manipulation of planting density may lead to increase in the economic yield of transplanted rice. Balanced fertilization right from the very beginning of crop growth is utmost essential to achieve better harvest of crop (Singh and Namdeo, 2004). Usually, rice yield declines when transplanting is delayed beyond the optimum time (Ologunde, 1987). The optimal date of transplanting of any field crop depends on the environmental conditions required for good growth and development. The farmer therefore seeks to manage the relationship between the crop and its 
environment in order to optimize growth and yield.

The present study is proposed to study growth parameters of rice varieties as influenced by combination of plant density and fertilizer levels under late sown conditions.

\section{MATERIAL AND METHODS}

Field experiment was conducted during the kharif season of 2014 and 2015 at Agricultural College Farm, Rajendranagar, and Hyderabad. The experimental site was geographically situated at an altitude of $542.6 \mathrm{~m}$ above mean sea level, on $17^{0} 19^{1} \mathrm{~N}$ latitude and $78^{0} 24^{1} \mathrm{E}$ longitude. It comes under Southern Telangana zone of Telangana. The soil was sandy clay loam in texture, neutral in reaction $(\mathrm{pH} 7.2)$ with $0.49 \%$ of organic matter, with low available nitrogen $\left(180.8 \mathrm{~kg} \mathrm{ha}^{-1}\right)$, high available phosphorus $\left(38.6 \mathrm{~kg} \mathrm{ha}^{-1}\right)$ and potassium $\left(312 \mathrm{~kg} \mathrm{ha}^{-1}\right)$.

The experiments were laid out in a split plot design with three replications. Three varieties MTU 1010, Rajendra and Pradyumna as main plot treatments, three plant densities $\left(\mathrm{P}_{1}: 20 \times 20 \mathrm{~cm}, \mathrm{P}_{2}: 15 \times 15 \mathrm{~cm}\right.$ and $\left.\mathrm{P}_{3:}: 15 \times 10 \mathrm{~cm}\right)$, three fertilizer levels ( $\mathrm{F}_{1:}$ 111-32-45, $\mathrm{F}_{2:}$ 153-59-68 and $\mathrm{F}_{3:}$ 195-86-90) as sub plot treatments.

The fertilizer levels111-32-45 kg NPK ha ${ }^{-1,} 153-59-68 \mathrm{~kg} \mathrm{NPK} \mathrm{ha}^{-1}$ and 195-86-90kg NPK ha- ${ }^{-1}$ were applied as 50 per cent $\mathrm{N}$, full dose of $\mathrm{P}$ and 50 per cent $\mathrm{K}$ at the time of transplanting. Nitrogen was applied as per the treatments in 3 split doses as basal $50 \%$ and at active tillering and panicle initiation stages $25 \%$ each. The remaining half of potassium was applied at panicle initiation stage.

\section{RESULTS AND DISCUSSIONS}

\section{Growth Parameters}

Plant Height

During both the years, an average plant height increased linearly up to 75 DAT and continued to increase until maturity at a diminishing rate. The plant height of rice as influenced by varieties and plant density in combination with fertility levels during both the years of study were analyzed statistically and presented in the table 1 and 1a. However, their interaction effect was not significant at all stages of crop growth.

Plant height of the varieties increased with advancement in age of the crop. Significantly taller plants were noticed with MTU 1010 at 30 DAT (43.35, 45.19 and $44.27 \mathrm{~cm}), 45$ DAT (67.30, 68.15 and $67.72 \mathrm{~cm}), 60$ DAT (84.56, 87.41 and $85.98 \mathrm{~cm}), 75$ DAT $(97.30,98.67$ and $97.98 \mathrm{~cm})$, and at maturity $(100.00,101.63$ and $100.81 \mathrm{~cm})$ over Rajendra and Pradyumna. The plant height of the varieties Rajendra and Pradyumna were found on par at all stages of the plant growth. The lowest plant height was observed in the variety Rajendra at all stages of the plant growth. The differential growth with respect to plant height observed among the varieties may be attributed to differences in genetic characteristics of the individual varieties, including rapid growth rates, tallness or shortness of species. Difference in plant height with different varieties was also observed by Priyadarsini (2001).Similar results were reported by Rao and Moorthy (1997), (Valarmathi and Leenakumary, 1998), Ghosh and Sharma (2000), Sudheer Kumar (2005) and Ramana et al., 2007.

The mean plant height was significantly higher in $\left(\mathrm{T}_{3}\right) v i z ., \mathrm{P}_{1}(20 \mathrm{~cm} \times 20 \mathrm{~cm})$ in combination with $\mathrm{F}_{3}$ fertility levels (195-86-90, N, $\left.\mathrm{P}_{2} \mathrm{O}_{5} \& \mathrm{~K}_{2} \mathrm{O} \mathrm{kg} \mathrm{ha}{ }^{-1}\right)$ at all stages of plant growth except at harvest, which was on par with $\mathrm{F}_{2}$ fertility levels (153-59-68 N, $\left.\mathrm{P}_{2} \mathrm{O}_{5} \& \mathrm{~K}_{2} \mathrm{O} \mathrm{kg} \mathrm{ha}^{-1}\right)$. Significantly lower plant height was recorded with $\left(\mathrm{T}_{7}\right) v i z ., \mathrm{P}_{3}(15 \mathrm{~cm} \times 10 \mathrm{~cm})$ in combination with $\mathrm{F}_{1}$ fertility levels (111-32-45, N, $\mathrm{P}_{2} \mathrm{O}_{5} \& \mathrm{~K}_{2} \mathrm{O} \mathrm{kg} \mathrm{ha}{ }^{-1}$ ) at all stages of the plant growth (Table 1 and 
1a).

The increase in plant height might be due to wider spacing, lesser competition among plants and timely availability of nutrients in right proportion at the critical stages of the growth. Availability of higher nutrition to the growing plant might have resulted in better growth of plant resulted in terms of higher plant height. High rate of nitrogen fertilizer contributing for higher availability of nitrogen which in turn resulted in stimulation of meristematic growth leading to increase in plant height at all the growth stages. These results are in agreement with the findings of Nayak et al. (2003), Sudheer Kumar (2005) Mahato et al., 2007, Chaudhary et al. (2007) and Yadav and Tripathi (2008).

\section{Number of Tillers Hill $^{-1}$ and Tillers $\mathbf{M}^{-2}$}

The average number of tillers hill ${ }^{-1}$ of rice increased linearly up to 60 DAT and thereafter it was declined slightly, which might be due to self thinning mechanism, resource constraint or intra plant competition being supported by Harish $e t$ al. (2011) and Pallakonda (2014).

The higher number of tillers hill ${ }^{-1}$ were recorded with MTU 1010 at 30 DAT (5.9, 5.9 and 5.9), 45 DAT (7.6, 7.7 and 7.6), 60 DAT (8.1, 8.3 and 8.2), 75 DAT (7.7, 7.9 and 7.8), and at maturity (7.6, 7.8 and 7.7) over Rajendra and Pradyumna during 20142015 and pooled means respectively(Table 2 and 2a).The higher number of tillers $\mathrm{m}^{-2}$ were also recorded with MTU 1010 at 30 DAT (232.8, 235.4 and 234.1), 45 DAT (298.6, 302.3 and 300.5), 60 DAT (318.2, 320.8 and 319.5), 75 DAT (297.4, 302.2 and 299.8), and at maturity (295.7, 300.4 and 298.1) over Rajendra and Pradyumna (Table 2 and 2a).This might be due to its higher tillering ability compared to other varieties; which can be attributed to the genetic make-up of the varieties. The present findings were in accordance with those of Priyadarsini (2001), Sudheer Kumar (2005) Ramana et al. (2007).

Significant increase in tillers hill ${ }^{-1}$ was observed with decrease in plant density in combination with increase in fertility levels. Number of tillers hill ${ }^{-1}$ varied due to crop geometry and fertility levels. Profused tillering hill ${ }^{-1}$ from 30 DAT to 60 DAT (Table 2 and 2a) was observed under wider spacing $\left(\mathrm{T}_{3}\right) v i z ., \mathrm{P}_{1}(20 \times 20 \mathrm{~cm})$ in combination with increased fertility levels, $\mathrm{F}_{3}\left(195-86-90 \mathrm{~N}, \mathrm{P}_{2} \mathrm{O}_{5} \& \mathrm{~K}_{2} \mathrm{O} \mathrm{kg} \mathrm{ha}{ }^{-1}\right)$. Number of tillers hill ${ }^{-1}$ was declined after 60 DAT which might be due to the mortality of tillers which were produced at later stages of crop growth. Though the number of tillers plant ${ }^{-1}$ were found to be higher with wider planting pattern $(20 \times 20 \mathrm{~cm})$, they could not compensate for the reduction of plant population per unit area and hence number of total tillers per unit area were more with closer planting pattern $(15 \times 10 \mathrm{~cm})($ Table 2 and 2a) during 2014, 2015 and pooled means. The number of tillers plant ${ }^{-1}$ was found to be higher due to better utilization of resources and lesser competition under wider spacing. These results are in agreement with the findings of Sudheer Kumar (2005), Veeranna and Raghu Rami Reddy (2010), Kumari et al., 2000 and Navneet Aggarwal and Avtar Singh (2015).

The interaction effect of varieties and plant density in combination with fertility levels on number of tillers hill ${ }^{-1}$ during both the years and in pooled means was found to be non significant.

\section{Dry Matter Production (DMP)}

Data pertaining to dry matter production $\left(\mathrm{kg} \mathrm{ha}^{-1}\right)$ are presented in Table 3 and 3a.The dry matter production was significantly affected by various treatments and varieties but the interaction effect was not significant at all the stages of crop growth. 
Significantly higher dry matter accumulation was recorded with MTU 1010 at all stages of crop growth over Rajendra and Pradyumna during kharif 2014, 2015 and pooled means, respectively. The percentage increase in dry matter (pooled) of MTU 1010 over Pradyumna and Rajendra was 13.18 and 20.62 at 30 DAT, 12.67 and 19.73 at 45 DAT, 12.44 and 19.37 at 60 DAT, 12.39 and 19.22 at 75 DAT and 12.38 and 19.23 at harvest.

Plant height (Table 1 and 1a), tiller number (Table. 2 and 2a,) might have been responsible for variation in dry matter production among the varieties. Similar results on dry matter production of varieties at all stages of sampling were reported by Tomar et al. (1994) and Prasada Rao et al. (2011).

\section{CONCLUSIONS}

Significantly higher dry matter was with $\left(\mathrm{T}_{9}\right)$ viz., $\mathrm{P}_{3}(15 \mathrm{~cm} \times 10 \mathrm{~cm})$ in combination with $\mathrm{F}_{3}\left(195-86-90, \mathrm{~N}, \mathrm{P}_{2} \mathrm{O}_{5}\right.$ $\left.\& \mathrm{~K}_{2} \mathrm{O}\right)$ and was significantly superior to $\mathrm{P}_{2}(15 \mathrm{~cm} \times 15 \mathrm{~cm})$ and $\mathrm{P}_{1}(20 \mathrm{~cm} \times 20 \mathrm{~cm})$ at all the growth stages of crop (2499, 2520, $2509 \mathrm{~kg}$ ha- ${ }^{1}$ at 30 DAT, 4589, 4626, $4608 \mathrm{~kg} \mathrm{ha}^{-}{ }^{1}$ at 45 DAT, 7354, 7378, $7366 \mathrm{~kg}$ ha- $^{1}$ at 60 DAT, 9961, 10007, $9984 \mathrm{~kg}$ ha- ${ }^{1}$ at 75 DAT and 13341, 13411, $13376 \mathrm{~kg}$ ha- ${ }^{1}$ at maturity during kharif 2014, 2015 and pooled means, respectively (Table 3 and 3a). This might be due to available nutrients present in soil which in results plant uptake of more NPK from the soil. The lower dry matter was observed in $\left(\mathrm{T}_{1}\right) v i z . \mathrm{P}_{1}(20 \mathrm{~cm} \times 20 \mathrm{~cm})$ in combination with $\mathrm{F}_{1}(111-32-45$, $\mathrm{N}, \mathrm{P}_{2} \mathrm{O}_{5} \& \mathrm{~K}_{2} \mathrm{O}$ ). The dry matter production per unit area was the manifestation of other growth parameters, and the highest dry matter production in closer planting pattern $(15 \times 10 \mathrm{~cm})$ might be due to more number of tillers and larger leaf area.This rapid dry matter production under closer spacing could be attributed to vertical growth of rice plants at closer spacing as compared to horizontal tillering in wider spacing (Yadav, 2007). The observed difference in dry matter production during development might be due to differential absorption of PAR due to variation in plant population and LAI, or differences in the efficiency of converting absorbed photosynthetic active radiation into dry matter (Tollenaar and Agui-lera, 1992). The reduction in dry matter $\left(\mathrm{kg} \mathrm{ha}^{-1}\right)$ under wider spacing could probably be due to the less number of hills compared to those in the crop with narrow spacing. Since there was a lack of compensatory mechanism in the luxuriant growth of widely spaced crops for the number of tillers per unit area despite profuse tillering per hill, the total phytomass reduced.These results are in accordance with findings of Kumari et al. (2000), where the highest dry matter was attained due to 100 hills $\mathrm{m}^{-2}$, over 66 and 33 hills $\mathrm{m}^{-2}$ in sandy clay loam soils of Bapatla. Similar results were also reported by Sudheer Kumar (2005) and Navneet Aggarwal and Avtar Singh (2015).

\section{REFERENCES}

1. Chaudhary, S.K., Thakur, S.K and Pandey, A.K. 2007. Responce of wet land rice (Oryza sativa L.) to nitrogen and zinc. Oryza. $44(1): 31-34$.

2. Ghosh, A and Sharma, A.R. 2000. Sowing time of rainfed lowland rice. Optimum time of sowing rice varieties under deepwater conditions. Oryza. 37: 222-225.

3. Harish, H., Deshpande and Devasenapathy, P. 2011. Effect of different organic sources of nutrients and green manure on growth and yield parameters of rice (Oryza sativa L.) grown under lowland condition. Crop Research. 41(1, 2 \&3) : 1-5

4. Kumari, M. B. G. S., Subbaiah, G., Veeraraghavaiah, R and Rao. H.G.V. 2000. Effect of plant density and nitrogen levels on growth and yield of rice. The Andhra Agricultural Journal. 47 (3 \& 4): 188-190.

5. Kumar, R.M., Surekha, K., Padmavathi, Ch., Rao, L.V.S., Latha, P.C., Prasad, M.S., Babu, V.R., Ramprasad, A.S., Rupela, O.P., Goud, P.V., Raman, P.M., Somashekar, N., Ravichandran, S., Singh, S.P and Viraktamath, B.C. 2009. Research 
experiences on System of Rice Intensification and future directions. Journal of Rice Research. 2 : 61-73.

6. Mahato, P., Gunri, S.K., Chanda, K and Ghosh, M. 2007. Effect of varying levels of fertilizer and spacing on medium duration rice (Oryza Sativa L.) in Tarai zone of West Bengal. Karnataka Journal of Agricultural Sciences. 20(2): 363-365.

7. Mohanty, S. 2013. Trends in global rice consumption. Rice Today: 44-45.

8. Navneet Aggarwal and Avtar Singh.2015. Crop performance, nutrient uptake vis-à-vis weed suppressive ability of mechanically transplanted rice (Oryza sativa) as influenced by age of seedlings and planting density. Indian Journal of Agronomy.60(2):255-260.

9. Nayak, B. C., Dalei, B. B. and Choudhury, B. K. 2003. Responce of hybrid rice (Oryza sativa) to date of planting, spacing and seedling rate during wet season. Indian Journal of Agronomy.48(3):172-174.

10. Ologunde, O.O. 1987. Institute of Agriculture research, ABU, Zaria. Samaru Miscellaneous Paper 118:4-6.

11. Pallakonda, R. 2014. Influence of planting methods and integrated nutrient management on growth, yield and quality of rice. PhD thesis. Department of Agronomy, ANGRAU, Hyderabad.

12. Prasada Rao, V., Subbaiah, G., Chandrasekhar, K and Prasuna Rani,P.2011. Validation of Nitrogen recommendations for popular rice (Oryza sativa L.) varieties of coastal Andhra Pradesh. The Andhra Agricultural Journal. 58(1): 1-4.

13. Priyadarsini, J.2001.Yield and quality of rice as affected by varieties and nitrogen source. M.Sc. (Ag) thesis submitted to Acharya N G Ranga Agricultural University, Hyderabad, India.

14. Ramana, A.V., Reddy, D.S and Reddy, K.R. 2007. Influence of sowing time and nitrogen levels on growth, yield and N uptake of rainfed upland rice (Oryza sativa L.) varieties. The Andhra Agricultural Journal. 54: 114-120.

15. Rao, R.S and Moorthy, B.T.S. 1997. Evaluation of yield potential of extra early and early rice varieties under graded nitrogen levels in dry season in Orrisa. Indian Journal of Agricultural sciences. 65: 467-472.

16. Singh, R.K and Namdeo, K.N. 2004. Effect of fertility levels and herbicides on growth, yield and nutrient uptake of directseeded rice (Oryza sativa). Indian Journal of Agronomy. 49 (1): 34-36.

17. Sudheer kumar, M.2005. Varietal Performance and Spatial requirements of Rice under System of Rice Intensification (SRI) during rabi season. M.Sc. (Ag.) Thesis. Acharya N G Ranga Agricultural University, Hyderabad, India.

18. Tollenaar, M and Aguilera, A. 1992. Radiation use efficiency of Anold and a new maize hybrid. Agronomy Journal. 84: 536541.

19. Tomar, P.S., Upadhyay, A and Sharma, J.K.1994.Effect of zinc on yield and nutritional quality of grain and straw of rice cultures. Annals of Plant Physiology. 8: 66-68.

20. Valarmathi, G and Leenakumary, S. 1998. Performance analysis of high yielding rice varieties of Kerala under direct seeded and transplanted conditions. Crop Research. 16 (2): 284-286.

21. Veeranna and Raghu Rami Reddy (2010). Performance of System of Rice Intensification under different planting geometry and age of seedlings. The Andhra Agricultural Journal. 57(4):397-399.

22. Yadav, V.K. 2007. Studies on the effect of dates of planting, plant geometry and number of seedlings per hill in hybrid rice (Oryza sativa l.). Ph D Thesis. Chandra Shekhar Azad University of Agriculture and Technology, Kanpur-208 002 (U.P.) India.

23. Yadav, V.K and Tripathi, H.N. 2008. Effect of dates of planting, plant geometry and number of seedlings on growth and yield of hybrid rice. Crop Research. 36(1,2\&3): 1-3. 


\section{APPENDICES}

Table 1: Plant Height (Cm) of Rice Varieties as Influenced by Combination of Plant Densities and Fertilizer Levels During Kharif 2014, 2015and Pooled Means

\begin{tabular}{|c|c|c|c|c|c|c|c|c|c|}
\hline \multirow{2}{*}{ Treatments } & \multicolumn{2}{|c|}{30 DAT } & \multirow[b]{2}{*}{ Pooled } & \multicolumn{2}{|c|}{45 DAT } & \multirow[b]{2}{*}{ Pooled } & \multicolumn{2}{|c|}{60 DAT } & \multirow[b]{2}{*}{ Pooled } \\
\hline & 2014 & 2015 & & 2014 & 2015 & & 2014 & 2015 & \\
\hline \multicolumn{10}{|c|}{$\begin{array}{c}\text { Main Treatments } \\
\text { (Varieties) }\end{array}$} \\
\hline $\mathrm{V}_{1}-\mathrm{MTU} 1010$ & 43.35 & 45.19 & 44.27 & 67.30 & 68.15 & 67.72 & 84.56 & 87.41 & 85.98 \\
\hline $\mathrm{V}_{2}$-Rajendra & 35.19 & 36.52 & 35.85 & 53.59 & 56.22 & 54.91 & 73.70 & 76.85 & 75.28 \\
\hline $\mathrm{V}_{3^{-}}$Pradyumna & 36.19 & 37.81 & 37.00 & 55.56 & 58.74 & 57.15 & 76.44 & 79.48 & 77.96 \\
\hline SEm \pm & 0.33 & 0.46 & 0.37 & 0.75 & 0.80 & 0.72 & 0.88 & 0.95 & 0.91 \\
\hline $\mathrm{CD}(0.05)$ & 1.31 & 1.82 & 1.43 & 2.96 & 3.14 & 2.82 & 3.47 & 3.72 & 3.59 \\
\hline \multicolumn{10}{|c|}{ Sub Treatments (Combination of Plant Density and Fertilizer Levels) } \\
\hline $\mathrm{T}_{1}-\mathrm{P}_{1} \mathrm{~F}_{1}$ & 36.28 & 36.89 & 36.58 & 55.89 & 58.33 & 57.11 & 76.89 & 79.44 & 78.17 \\
\hline $\mathrm{T}_{2}-\mathrm{P}_{1} \mathrm{~F}_{2}$ & 41.22 & 42.78 & 42.00 & 63.44 & 65.11 & 64.28 & 82.78 & 85.78 & 84.28 \\
\hline $\mathrm{T}_{3}-\mathrm{P}_{1} \mathrm{~F}_{3}$ & 42.44 & 44.78 & 43.61 & 65.56 & 67.78 & 66.67 & 85.67 & 88.56 & 87.11 \\
\hline $\mathrm{T}_{4}-\mathrm{P}_{2} \mathrm{~F}_{1}$ & 34.22 & 35.11 & 34.67 & 52.78 & 55.89 & 54.33 & 73.56 & 76.56 & 75.06 \\
\hline $\mathrm{T}_{5}-\mathrm{P}_{2} \mathrm{~F}_{2}$ & 39.22 & 40.78 & 40.00 & 59.78 & 62.56 & 61.17 & 79.67 & 82.78 & 81.22 \\
\hline $\mathrm{T}_{6}-\mathrm{P}_{2} \mathrm{~F}_{3}$ & 41.00 & 42.89 & 41.94 & 62.22 & 64.78 & 63.50 & 82.33 & 85.22 & 83.78 \\
\hline $\mathrm{T}_{7}-\mathrm{P}_{3} \mathrm{~F}_{1}$ & 32.56 & 34.33 & 33.44 & 51.56 & 53.11 & 52.33 & 69.67 & 73.33 & 71.50 \\
\hline $\mathrm{T}_{8}-\mathrm{P}_{3} \mathrm{~F}_{2}$ & 37.78 & 39.44 & 38.61 & 57.67 & 59.67 & 58.67 & 75.56 & 78.78 & 77.17 \\
\hline $\mathrm{T}_{9}-\mathrm{P}_{3} \mathrm{~F}_{3}$ & 39.44 & 41.56 & 40.50 & 60.44 & 62.11 & 61.28 & 78.00 & 80.78 & 79.39 \\
\hline SEm \pm & 0.50 & 0.51 & 0.44 & 0.84 & 0.83 & 0.76 & 0.96 & 0.99 & 0.96 \\
\hline $\mathrm{CD}(0.05)$ & 1.42 & 1.44 & 1.26 & 2.38 & 2.35 & 2.16 & 2.73 & 2.82 & 2.74 \\
\hline \multicolumn{10}{|c|}{ Interaction } \\
\hline $\mathrm{SEm} \pm(\mathrm{Vx} T)$ & 0.88 & 0.95 & 0.81 & 1.56 & 1.57 & 1.43 & 1.80 & 1.88 & 1.82 \\
\hline $\mathrm{CD}(0.05)$ & NS & NS & NS & NS & NS & NS & NS & NS & NS \\
\hline SEm $\pm(\mathrm{TxV})$ & 0.86 & 0.88 & 0.77 & 1.45 & 1.43 & 1.31 & 1.66 & 1.72 & 1.67 \\
\hline $\mathrm{CD}(0.05)$ & NS & NS & NS & NS & NS & NS & NS & NS & NS \\
\hline
\end{tabular}

$\mathrm{P}_{1}: 25$ hills $/ \mathrm{m}^{2}(20 \times 20 \mathrm{~cm}), \mathrm{P}_{2}: 44$ hills $/ \mathrm{m}^{2}(15 \times 15 \mathrm{~cm}), \mathrm{P}_{3}: 66$ hills $/ \mathrm{m}^{2}(15 \times 10 \mathrm{~cm}) ; \mathrm{F}_{1:}: 111-32-45, \mathrm{~F}_{2}: 153-59-68, \mathrm{~F}_{3}: 195-$ $86-90 \mathrm{~kg}$

Table 1a: Plant Height (Cm) of Rice Varieties as Influenced by Combination of Plant Densities and Fertilizer Levels during Kharif 2014, 2015 and Pooled Means

\begin{tabular}{|l|c|c|c|c|c|c|}
\hline \multirow{2}{*}{ Treatments } & \multicolumn{2}{|c|}{ 75 DAT } & & \multicolumn{2}{c|}{ At Harvest } & \\
\cline { 2 - 7 } & $\mathbf{2 0 1 4}$ & $\mathbf{2 0 1 5}$ & Pooled & $\mathbf{2 0 1 4}$ & $\mathbf{2 0 1 5}$ & Pooled \\
\hline Main treatments (Varieties) & & & & & & \\
\hline $\mathrm{V}_{1}-$ MTU 1010 & 97.30 & 98.67 & 97.98 & 100.00 & 101.63 & 100.81 \\
\hline $\mathrm{V}_{2}-$ Rajendra & 84.11 & 85.70 & 84.91 & 84.44 & 85.85 & 85.15 \\
\hline $\mathrm{V}_{3}$ - Pradyumna & 87.41 & 88.81 & 88.11 & 87.59 & 89.04 & 88.31 \\
\hline $\mathrm{SEm} \pm$ & 1.05 & 1.18 & 1.11 & 1.00 & 1.17 & 1.08 \\
\hline $\mathrm{CD}(0.05)$ & 4.13 & 4.62 & 4.37 & 3.94 & 4.60 & 4.25 \\
\hline \multicolumn{5}{|c|}{ Sub Treatments( Combination of Plant Density and Fertilizer Levels) } \\
\hline $\mathrm{T}_{1}-\mathrm{P}_{1} \mathrm{~F}_{1}$ & 87.89 & 88.89 & 88.39 & 88.78 & 90.00 & 89.39 \\
\hline $\mathrm{T}_{2}-\mathrm{P}_{1} \mathrm{~F}_{2}$ & 95.11 & 96.67 & 95.89 & 96.11 & 97.78 & 96.94 \\
\hline $\mathrm{T}_{3}-\mathrm{P}_{1} \mathrm{~F}_{3}$ & 98.67 & 99.67 & 99.17 & 99.67 & 100.67 & 100.17 \\
\hline $\mathrm{T}_{4}-\mathrm{P}_{2} \mathrm{~F}_{1}$ & 83.89 & 85.44 & 84.67 & 84.89 & 86.44 & 85.67 \\
\hline $\mathrm{T}_{5}-\mathrm{P}_{2} \mathrm{~F}_{2}$ & 91.33 & 92.78 & 92.06 & 92.22 & 94.00 & 93.11 \\
\hline $\mathrm{T}_{6}-\mathrm{P}_{2} \mathrm{~F}_{3}$ & 94.67 & 95.89 & 95.28 & 95.67 & 97.00 & 96.33 \\
\hline $\mathrm{T}_{7}-\mathrm{P}_{3} \mathrm{~F}_{1}$ & 79.22 & 81.56 & 80.39 & 80.67 & 82.56 & 81.61 \\
\hline $\mathrm{T}_{8}-\mathrm{P}_{3} \mathrm{~F}_{2}$ & 86.44 & 88.00 & 87.22 & 87.44 & 89.00 & 88.22 \\
\hline $\mathrm{T}_{9}-\mathrm{P}_{3} \mathrm{~F}_{3}$ & 89.22 & 90.67 & 89.94 & 90.67 & 92.11 & 91.39 \\
\hline $\mathrm{SEm}_{ \pm} \mathrm{CD}_{ \pm}(0.05)$ & 1.16 & 1.17 & 1.15 & 1.18 & 1.17 & 1.16 \\
\hline $\mathrm{CD}_{2}(0.05$ & 3.29 & 3.32 & 3.26 & 3.36 & 3.33 & 3.29 \\
\hline
\end{tabular}




\begin{tabular}{|l|c|c|c|c|c|c|}
\hline \multicolumn{7}{|c|}{ Table 1.a: Contd., } \\
\hline \multicolumn{7}{|c|}{ Interaction } \\
\hline $\mathrm{SEm} \pm(\mathrm{Vx}) \mathrm{T})$ & 2.16 & 2.24 & 2.18 & 2.17 & 2.24 & 2.18 \\
\hline $\mathrm{CD}(0.05)$ & $\mathrm{NS}$ & $\mathrm{NS}$ & $\mathrm{NS}$ & NS & NS & NS \\
\hline $\mathrm{SEm} \pm(\mathrm{TxV})$ & 2.00 & 2.03 & 1.98 & 2.04 & 2.03 & 2.00 \\
\hline $\mathrm{CD}(0.05)$ & $\mathrm{NS}$ & $\mathrm{NS}$ & $\mathrm{NS}$ & $\mathrm{NS}$ & $\mathrm{NS}$ & NS \\
\hline
\end{tabular}

$\mathrm{P}_{1}: 25$ hills $/ \mathrm{m}^{2}(20 \times 20 \mathrm{~cm}), \mathrm{P}_{2}: 44$ hills $/ \mathrm{m}^{2}(15 \times 15 \mathrm{~cm}), \mathrm{P}_{3}: 66$ hills $/ \mathrm{m}^{2}(15 \times 10 \mathrm{~cm}) ; \mathrm{F}_{1:} 111-32-45, \mathrm{~F}_{2}: 153-59-68, \mathrm{~F}_{3}: 195-$ $86-90 \mathrm{~kg} \mathrm{ha}^{-1}$

Table 2: Number of Tillers $\mathbf{m}^{-2}$ of Rice Varieties as Influenced by Combination of Plant Densities and Fertilizer Levels during kharif 2014, 2015 and Pooled Means

\begin{tabular}{|c|c|c|c|c|c|c|c|c|c|}
\hline \multirow{2}{*}{ Treatments } & \multicolumn{2}{|c|}{30 DAT } & \multirow[b]{2}{*}{ Pooled } & \multicolumn{2}{|c|}{45 DAT } & \multirow[b]{2}{*}{ Pooled } & \multicolumn{2}{|c|}{ 60 DAT } & \multirow[b]{2}{*}{ Poolec } \\
\hline & 2014 & 2015 & & 2014 & 2015 & & 2014 & 2015 & \\
\hline \multicolumn{10}{|l|}{$\begin{array}{c}\text { Main Treatments } \\
\text { (Varieties) }\end{array}$} \\
\hline $\mathrm{V}_{1-}-\mathrm{MTU} 1010$ & 43.35 & 45.19 & 44.27 & 67.30 & 68.15 & 67.72 & 84.56 & 87.41 & 85.98 \\
\hline $\mathrm{V}_{2}$-Rajendra & 35.19 & 36.52 & 35.85 & 53.59 & 56.22 & 54.91 & 73.70 & 76.85 & 75.28 \\
\hline $\mathrm{V}_{3^{-}}$Pradyumna & 36.19 & 37.81 & 37.00 & 55.56 & 58.74 & 57.15 & 76.44 & 79.48 & 77.96 \\
\hline SEm \pm & 0.33 & 0.46 & 0.37 & 0.75 & 0.80 & 0.72 & 0.88 & 0.95 & 0.91 \\
\hline $\mathrm{CD}(0.05)$ & 1.31 & 1.82 & 1.43 & 2.96 & 3.14 & 2.82 & 3.47 & 3.72 & 3.59 \\
\hline \multicolumn{10}{|c|}{ Sub Treatments (Combination of Plant Density and Fertilizer Levels) } \\
\hline $\mathrm{T}_{1}-\mathrm{P}_{1} \mathrm{~F}_{1}$ & 36.28 & 36.89 & 36.58 & 55.89 & 58.33 & 57.11 & 76.89 & 79.44 & 78.17 \\
\hline $\mathrm{T}_{2}-\mathrm{P}_{1} \mathrm{~F}_{2}$ & 41.22 & 42.78 & 42.00 & 63.44 & 65.11 & 64.28 & 82.78 & 85.78 & 84.28 \\
\hline $\mathrm{T}_{3}-\mathrm{P}_{1} \mathrm{~F}_{3}$ & 42.44 & 44.78 & 43.61 & 65.56 & 67.78 & 66.67 & 85.67 & 88.56 & 87.11 \\
\hline $\mathrm{T}_{4}-\mathrm{P}_{2} \mathrm{~F}_{1}$ & 34.22 & 35.11 & 34.67 & 52.78 & 55.89 & 54.33 & 73.56 & 76.56 & 75.06 \\
\hline $\mathrm{T}_{5}-\mathrm{P}_{2} \mathrm{~F}_{2}$ & 39.22 & 40.78 & 40.00 & 59.78 & 62.56 & 61.17 & 79.67 & 82.78 & 81.22 \\
\hline $\mathrm{T}_{6}-\mathrm{P}_{2} \mathrm{~F}_{3}$ & 41.00 & 42.89 & 41.94 & 62.22 & 64.78 & 63.50 & 82.33 & 85.22 & 83.78 \\
\hline $\mathrm{T}_{7}-\mathrm{P}_{3} \mathrm{~F}_{1}$ & 32.56 & 34.33 & 33.44 & 51.56 & 53.11 & 52.33 & 69.67 & 73.33 & 71.50 \\
\hline $\mathrm{T}_{8}-\mathrm{P}_{3} \mathrm{~F}_{2}$ & 37.78 & 39.44 & 38.61 & 57.67 & 59.67 & 58.67 & 75.56 & 78.78 & 77.17 \\
\hline $\mathrm{T}_{9}-\mathrm{P}_{3} \mathrm{~F}_{3}$ & 39.44 & 41.56 & 40.50 & 60.44 & 62.11 & 61.28 & 78.00 & 80.78 & 79.39 \\
\hline SEm \pm & 0.50 & 0.51 & 0.44 & 0.84 & 0.83 & 0.76 & 0.96 & 0.99 & 0.96 \\
\hline $\mathrm{CD}(0.05)$ & 1.42 & 1.44 & 1.26 & 2.38 & 2.35 & 2.16 & 2.73 & 2.82 & 2.74 \\
\hline \multicolumn{10}{|c|}{ Interaction } \\
\hline $\operatorname{SEm} \pm(\mathrm{Vx} T)$ & 0.88 & 0.95 & 0.81 & 1.56 & 1.57 & 1.43 & 1.80 & 1.88 & 1.82 \\
\hline $\mathrm{CD}(0.05)$ & NS & NS & NS & NS & NS & NS & NS & NS & NS \\
\hline SEm $\pm(T x V)$ & 0.86 & 0.88 & 0.77 & 1.45 & 1.43 & 1.31 & 1.66 & 1.72 & 1.67 \\
\hline $\mathrm{CD}(0.05)$ & NS & NS & NS & NS & NS & NS & NS & NS & NS \\
\hline
\end{tabular}

$\mathrm{P}_{1}: 25$ hills $/ \mathrm{m}^{2}(20 \times 20 \mathrm{~cm}), \mathrm{P}_{2}: 44$ hills $/ \mathrm{m}^{2}(15 \times 15 \mathrm{~cm}), \mathrm{P}_{3}: 66$ hills $/ \mathrm{m}^{2}(15 \times 10 \mathrm{~cm}) ; \mathrm{F}_{1:}$ 111-32-45, $\mathrm{F}_{2:}$ 153-59-68, $\mathrm{F}_{3}: 195-$

$86-90 \mathrm{~kg} \mathrm{ha}$

Table 2a: Number of Tillers $\mathrm{M}^{-2}$ of Rice Varieties As Influenced by Combination of Plant Densities and Fertilizer Levels during Kharif 2014, 2015 and Pooled Means

\begin{tabular}{|l|c|c|c|c|c|c|}
\hline \multirow{2}{*}{ Treatments } & \multicolumn{3}{|c|}{ 75 DAT } & \multicolumn{3}{c|}{ At harvest } \\
\cline { 2 - 7 } & $\mathbf{2 0 1 4}$ & $\mathbf{2 0 1 5}$ & Pooled & $\mathbf{2 0 1 4}$ & $\mathbf{2 0 1 5}$ & Pooled \\
\hline Main Treatments (Varieties) & \multicolumn{7}{|c|}{} & & & \\
\hline $\mathrm{V}_{1}$ - MTU 1010 & 297.4 & 302.2 & 299.8 & 295.7 & 300.4 & 298.1 \\
\hline $\mathrm{V}_{2}$-Rajendra & 274.9 & 281.7 & 278.3 & 267.7 & 274.8 & 271.2 \\
\hline $\mathrm{V}_{3}$-Pradyumna & 285.3 & 287.3 & 286.3 & 279.9 & 282.4 & 281.1 \\
\hline $\mathrm{SEm} \pm$ & 3.3 & 4.0 & 3.48 & 4.0 & 4.8 & 3.76 \\
\hline $\mathrm{CD}(0.05)$ & 13.0 & 15.7 & 13.7 & 15.6 & 18.9 & 14.8 \\
\hline Sub Treatments( Combination of Plant Density and Fertilizer Levels) & & & \\
\hline $\mathrm{T}_{1}-\mathrm{P}_{1} \mathrm{~F}_{1}$ & 226.8 & 234.0 & 230.4 & 224.2 & 228.8 & 226.5 \\
\hline $\mathrm{T}_{2}-\mathrm{P}_{1} \mathrm{~F}_{2}$ & 252.6 & 252.4 & 252.5 & 249.9 & 252.3 & 251.1 \\
\hline
\end{tabular}




\begin{tabular}{|c|c|c|c|c|c|c|}
\hline \multicolumn{7}{|c|}{ Table 2.a: Contd., } \\
\hline $\mathrm{T}_{3}-\mathrm{P}_{1} \mathrm{~F}_{3}$ & 262.8 & 265.7 & 264.2 & 260.2 & 265.6 & 262.9 \\
\hline $\mathrm{T}_{4}-\mathrm{P}_{2} \mathrm{~F}_{1}$ & 265.1 & 268.6 & 266.8 & 260.2 & 263.8 & 262.0 \\
\hline $\mathrm{T}_{5}-\mathrm{P}_{2} \mathrm{~F}_{2}$ & 285.9 & 292.3 & 289.1 & 281.1 & 287.7 & 284.4 \\
\hline $\mathrm{T}_{6}-\mathrm{P}_{2} \mathrm{~F}_{3}$ & 308.8 & 319.2 & 314.0 & 304.2 & 314.4 & 309.3 \\
\hline $\mathrm{T}_{7}-\mathrm{P}_{3} \mathrm{~F}_{1}$ & 296.9 & 302.8 & 299.8 & 289.7 & 295.7 & 292.7 \\
\hline $\mathrm{T}_{8}-\mathrm{P}_{3} \mathrm{~F}_{2}$ & 326.3 & 328.2 & 327.3 & 319.4 & 321.3 & 320.4 \\
\hline $\mathrm{T}_{9}-\mathrm{P}_{3} \mathrm{~F}_{3}$ & 347.7 & 350.4 & 349.1 & 340.8 & 343.3 & 342.1 \\
\hline SEm \pm & 8.8 & 6.8 & 5.9 & 8.5 & 6.9 & 5.9 \\
\hline $\mathrm{CD}(0.05)$ & 25.0 & 19.3 & 16.7 & 24.3 & 19.7 & 16.7 \\
\hline \multicolumn{7}{|c|}{ Interaction } \\
\hline $\mathrm{SEm} \pm(\mathrm{Vx} T)$ & 14.7 & 11.8 & 10.2 & 14.5 & 12.3 & 10.3 \\
\hline $\mathrm{CD}(0.05)$ & NS & NS & NS & NS & NS & NS \\
\hline SEm $\pm(\mathrm{TxV})$ & 15.2 & 11.8 & 10.2 & 14.8 & 12.0 & 10.18 \\
\hline $\mathrm{CD}(0.05)$ & $\mathrm{NS}$ & NS & $\mathrm{NS}$ & $\mathrm{NS}$ & $\mathrm{NS}$ & NS \\
\hline
\end{tabular}

$\mathrm{P}_{1}: 25$ hills $/ \mathrm{m}^{2}(20 \times 20 \mathrm{~cm}), \mathrm{P}_{2}: 44$ hills $/ \mathrm{m}^{2}(15 \times 15 \mathrm{~cm}), \mathrm{P}_{3}: 66$ hills $/ \mathrm{m}^{2}(15 \times 10 \mathrm{~cm}) ; \mathrm{F}_{1:}: 111-32-45, \mathrm{~F}_{2:}$ 153-59-68, $\mathrm{F}_{3}: 195-$ $86-90 \mathrm{~kg} \mathrm{ha}^{-1}$

Table 3: Dry Matter Accumulation (Kg Ha-1) of Rice Varieties as Influenced By Combination of Plant Densities and Fertilizer Levels During Kharif 2014, 2015 and Pooled Means

\begin{tabular}{|c|c|c|c|c|c|c|c|c|c|}
\hline \multirow{2}{*}{ Treatments } & \multicolumn{3}{|c|}{$30 \mathrm{DAT}$} & \multicolumn{3}{|c|}{45 DAT } & \multicolumn{3}{|c|}{60 DAT } \\
\hline & 2014 & 2015 & Pooled & 2014 & 2015 & Pooled & 2014 & 2015 & Pooled \\
\hline \multicolumn{10}{|c|}{$\begin{array}{c}\text { Main Treatments } \\
\text { (Varieties) }\end{array}$} \\
\hline V1- MTU 1010 & 2248 & 2269 & 2258 & 4144 & 4182 & 4163 & 6656 & 6682 & 6669 \\
\hline V2-Rajendra & 1861 & 1883 & 1872 & 3457 & 3496 & 3477 & 5570 & 5605 & 5587 \\
\hline V3- Pradyumna & 1984 & 2006 & 1995 & 3676 & 3715 & 3695 & 5914 & 5947 & 5931 \\
\hline SEm \pm & 23.5 & 24.5 & 24.0 & 41.8 & 43.6 & 42.6 & 69.0 & 70.1 & 69.5 \\
\hline $\mathrm{CD}(0.05)$ & 92.4 & 96.0 & 94.1 & 164.0 & 171.0 & 167.4 & 271.0 & 275.0 & 272.8 \\
\hline \multicolumn{10}{|c|}{ Sub Treatments( Combination of Plant Density and Fertilizer Levels) } \\
\hline $\mathrm{T}_{1}-\mathrm{P}_{1} \mathrm{~F}_{1}$ & 1543 & 1561 & 1552 & 2892 & 2924 & 2908 & 4680 & 4707 & 4694 \\
\hline $\mathrm{T}_{2}-\mathrm{P}_{1} \mathrm{~F}_{2}$ & 1695 & 1715 & 1705 & 3162 & 3199 & 3180 & 5107 & 5138 & 5123 \\
\hline $\mathrm{T}_{3}-\mathrm{P}_{1} \mathrm{~F}_{3}$ & 1763 & 1786 & 1774 & 3283 & 3324 & 3303 & 5298 & 5335 & 5316 \\
\hline $\mathrm{T}_{4}-\mathrm{P}_{2} \mathrm{~F}_{1}$ & 1889 & 1909 & 1899 & 3507 & 3542 & 3525 & 5649 & 5677 & 5663 \\
\hline $\mathrm{T}_{5}-\mathrm{P}_{2} \mathrm{~F}_{2}$ & 2038 & 2061 & 2050 & 3771 & 3812 & 3792 & 6067 & 6101 & 6084 \\
\hline $\mathrm{T}_{6}-\mathrm{P}_{2} \mathrm{~F}_{3}$ & 2155 & 2183 & 2169 & 3979 & 4029 & 4004 & 6394 & 6442 & 6418 \\
\hline $\mathrm{T}_{7}-\mathrm{P}_{3} \mathrm{~F}_{1}$ & 2252 & 2274 & 2263 & 4150 & 4191 & 4170 & 6663 & 6694 & 6679 \\
\hline $\mathrm{T}_{8}-\mathrm{P}_{3} \mathrm{~F}_{2}$ & 2446 & 2466 & 2456 & 4496 & 4531 & 4513 & 7206 & 7228 & 7217 \\
\hline $\mathrm{T}_{9}-\mathrm{P}_{3} \mathrm{~F}_{3}$ & 2499 & 2520 & 2509 & 4589 & 4626 & 4608 & 7354 & 7378 & 7366 \\
\hline SEm \pm & 39.3 & 38.2 & 38.7 & 69.8 & 67.8 & 68.7 & 106.7 & 104.9 & 105.7 \\
\hline $\mathrm{CD}(0.05)$ & 111.8 & 108.7 & 110.1 & 198.4 & 192.9 & 195.4 & 303.3 & 298.3 & 300.5 \\
\hline \multicolumn{10}{|c|}{ Interaction } \\
\hline $\mathrm{SEm} \pm(\mathrm{Vx} T)$ & 68.4 & 67.1 & 67.6 & 121.3 & 119.0 & 120.1 & 187.4 & 185.1 & 186.0 \\
\hline $\mathrm{CD}(0.05)$ & NS & NS & NS & NS & NS & NS & $\mathrm{NS}$ & NS & NS \\
\hline SEm $\pm(\mathrm{TxV})$ & 68.1 & 66.2 & 67.1 & 120.8 & 117.5 & 119.0 & 184.8 & 181.7 & 183.1 \\
\hline $\mathrm{CD}(0.05)$ & NS & NS & NS & NS & NS & NS & NS & NS & NS \\
\hline
\end{tabular}

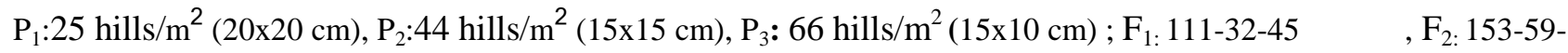

$68, \mathrm{~F}_{3}: 195-86-90 \mathrm{~kg} \mathrm{ha}^{-1}$ 
Table 3a: Dry Matter Accumulation $\left(\mathrm{Kg} \mathrm{Ha}^{-1}\right)$ of Rice Varieties as Influenced by Combination of Plant Densities and Fertilizer Levels during Kharif 2014, 2015 and Pooled Means

\begin{tabular}{|c|c|c|c|c|c|c|}
\hline \multirow{2}{*}{ Treatments } & \multicolumn{3}{|c|}{75 DAT } & \multicolumn{3}{|c|}{ At harvest } \\
\hline & 2014 & 2015 & Pooled & 2014 & 2015 & Pooled \\
\hline \multicolumn{7}{|c|}{$\begin{array}{c}\text { Main Treatments } \\
\text { (Varieties) }\end{array}$} \\
\hline V1- MTU 1010 & 9022 & 9062 & 9042 & 12093 & 12158 & 12125 \\
\hline V2-Rajendra & 7560 & 7608 & 7584 & 10143 & 10194 & 10169 \\
\hline V3- Pradyumna & 8023 & 8067 & 8045 & 10758 & 10819 & 10789 \\
\hline SEm \pm & 93.3 & 96.8 & 94.9 & 127.8 & 130.5 & 129.0 \\
\hline $\mathrm{CD}(0.05)$ & 366.4 & 380.0 & 372.8 & 501.9 & 512.3 & 506.6 \\
\hline \multicolumn{7}{|c|}{ Sub Treatments( Combination of Plant Density and Fertilizer Levels) } \\
\hline $\mathrm{T}_{1}-\mathrm{P}_{1} \mathrm{~F}_{1}$ & 6363 & 6400 & 6382 & 8548 & 8597 & 8573 \\
\hline $\mathrm{T}_{2}-\mathrm{P}_{1} \mathrm{~F}_{2}$ & 6938 & 6980 & 6959 & 9316 & 9355 & 9335 \\
\hline $\mathrm{T}_{3}-\mathrm{P}_{1} \mathrm{~F}_{3}$ & 7195 & 7244 & 7219 & 9657 & 9707 & 9682 \\
\hline $\mathrm{T}_{4}-\mathrm{P}_{2} \mathrm{~F}_{1}$ & 7667 & 7705 & 7686 & 10285 & 10338 & 10311 \\
\hline $\mathrm{T}_{5}-\mathrm{P}_{2} \mathrm{~F}_{2}$ & 8229 & 8275 & 8252 & 11036 & 11098 & 11067 \\
\hline $\mathrm{T}_{6}-\mathrm{P}_{2} \mathrm{~F}_{3}$ & 8670 & 8734 & 8702 & 11622 & 11694 & 11658 \\
\hline $\mathrm{T}_{7}-\mathrm{P}_{3} \mathrm{~F}_{1}$ & 9031 & 9073 & 9052 & 12102 & 12164 & 12133 \\
\hline $\mathrm{T}_{8}-\mathrm{P}_{3} \mathrm{~F}_{2}$ & 9761 & 9791 & 9776 & 13075 & 13151 & 13113 \\
\hline $\mathrm{T}_{9}-\mathrm{P}_{3} \mathrm{~F}_{3}$ & 9961 & 10007 & 9984 & 13341 & 13411 & 13376 \\
\hline SEm \pm & 143.6 & 140.7 & 142.0 & 189.2 & 187.9 & 188.5 \\
\hline $\mathrm{CD}(0.05)$ & 408.4 & 400.1 & 403.9 & 538.0 & 534.3 & 535.9 \\
\hline \multicolumn{7}{|c|}{ Interaction } \\
\hline $\mathrm{SEm} \pm(\mathrm{Vx} T)$ & 252.4 & 249.3 & 250.6 & 334.4 & 333.5 & 333.7 \\
\hline $\mathrm{CD}(0.05)$ & NS & NS & NS & NS & NS & NS \\
\hline SEm $\pm(\mathrm{TxV})$ & 248.8 & 243.7 & 246.0 & 327.7 & 325.5 & 326.4 \\
\hline $\mathrm{CD}(0.05)$ & NS & NS & NS & NS & NS & NS \\
\hline
\end{tabular}

$\mathrm{P}_{1}: 25$ hills $/ \mathrm{m}^{2}(20 \times 20 \mathrm{~cm}), \mathrm{P}_{2}: 44$ hills $/ \mathrm{m}^{2}(15 \times 15 \mathrm{~cm}), \mathrm{P}_{3}: 66$ hills $/ \mathrm{m}^{2}(15 \times 10 \mathrm{~cm}) ; \mathrm{F}_{1: 1}$ 111-32-45, $\mathrm{F}_{2:}$ 153-59-68, $\mathrm{F}_{3}$ : $195-86-90 \mathrm{~kg} \mathrm{ha}^{-1}$ 
